\title{
Assessing nitrate origin in a volcanic aquifer using a dual isotope approach
}

\author{
G. Mongelli $\cdot$ M. Paternoster $\cdot$ R. Sinisi
}

Received: 9 July 2012/Revised: 12 November 2012/Accepted: 23 December 2012/Published online: 26 January 2013

(C) Islamic Azad University (IAU) 2013

\begin{abstract}
Identifying the origin of nitrate is important for the control and management of groundwater quality in aquifer systems. In the southern Apennines (Italy), the Mount Vulture volcanic aquifer is a large and valuable resource of potable and mineral water supply. Unfortunately, signs of anthropogenic impact, especially nitrogen contamination, have recently become evident. In this study, and for the first time, stable isotope ratios $\left(\delta^{15} \mathrm{~N}\right.$ and $\left.\delta^{18} \mathrm{O}\right)$ of $\mathrm{NO}_{3}{ }^{-}$were determined in groundwater to identify their origins and evaluate the presence of transformation processes. The Mount Vulture groundwaters are meteoric in origin, as demonstrated by measurements of $\delta \mathrm{D}$ and $\delta^{18} \mathrm{O}$, and can be divided into two distinct areas based on their $\mathrm{NO}_{3}{ }^{-}$content. In the southeastern area, characterized by active agricultural land use, the high $\mathrm{NO}_{3}{ }^{-}$content and the $\delta{ }^{15} \mathrm{~N}-\mathrm{NO}_{3}$ isotopic values are due to anthropogenic contamination (inorganic fertilizer). In groundwaters from the western area, the $\mathrm{NO}_{3}{ }^{-}$contents below $4 \mathrm{mg} / \mathrm{L}$ and the $\delta^{15} \mathrm{~N}-\mathrm{NO}_{3}$ values can be associated at organic soil $\mathrm{N}$. Evidence for local denitrification may be assumed in a few groundwater samples of the western area showing relatively heavy $\delta^{15} \mathrm{~N}$ values and low concentrations of nitrate. Finally, the low measured $\delta^{18} \mathrm{O}$ values indicate that nitrification occurred in both investigated areas.
\end{abstract}

Keywords Anthropogenic contamination - Groundwater . Nitrification $\cdot$ Nitrogen and oxygen isotopes

G. Mongelli $\cdot$ M. Paternoster $(\bowtie)$

Department of Sciences, University of Basilicata,

Campus Macchia Romana, 85100 Potenza, Italy

e-mail: michele.paternoster@unibas.it

R. Sinisi

Department of Nature and Earth Sciences, University of Sassari,

Via Piandanna 4, 07100 Sassari, Italy

\section{Introduction}

The Mount (Mt. thereafter) Vulture basin represents one of the most important aquifer systems of southern Italy. Groundwater in this aquifer is an important and valuable resource for potable and mineral water supply, and agricultural and industrial uses. Groundwater extraction, which started in the 1940s, has been gradually increased during recent years to satisfy the rising water demand. However, signs of anthropogenic impact, especially nitrogen contamination, have recently become evident (Parisi et al. 2011a; Paternoster et al. 2010). The European Union standard for drinking and mineral water quality is $50 \mathrm{mg} / \mathrm{L}$ of $\mathrm{NO}_{3}{ }^{-}$(EU directive 1998/83/EC; EU directive 2003/40/ EC, respectively). The World Health Organization has set a limit of $44.3 \mathrm{mg} / \mathrm{L}$ of $\mathrm{NO}_{3}{ }^{-}$for drinking water, to protect infants from ingesting groundwater high in nitrate. The isotopic composition $\left(\delta^{15} \mathrm{~N}\right)$ of dissolved nitrate has been extensively used to provide information on the origins and transformations of inorganic $\mathrm{N}$ in the hydrosphere (Heaton 1986). Nitrate $\left(\mathrm{NO}_{3}{ }^{-}\right)$is found naturally in moderate concentrations in many aquatic environments, but its concentration is often increased due to the use of nitrogencontaining fertilizers (Chae et al. 2009; Choi et al. 2011) and the discharge of waste water and manure (Benkovitz et al. 1996; Choi et al. 2007). Liu et al. (2006) reported that these sources produce nitrate with distinguishable ${ }^{15} \mathrm{~N} /{ }^{14} \mathrm{~N}$ ratios: $\delta^{15} \mathrm{~N}$ values are from -1 to $+2 \%$ for synthetic fertilizer, from +2 to $+8 \%$ for soil organic nitrogen, and from +8 to $+20 \%$ for livestock waste and sewage. However, a disadvantage of the single isotope approach is its inability to identify sources and transformation of $\mathrm{NO}_{3}{ }^{-}$ in groundwater due to the non-conservative behavior of nitrogen in the earth's surface (Kendall 1998). In fact, nitrogen is biologically modified through, for example, 
denitrification reactions that cause isotope fractionation and modify the isotope composition of the dissolved $\mathrm{N}$ species (Silva et al. 2000). Denitrification can cause enrichment in heavy isotope of nitrogen and oxygen in the residual $\mathrm{NO}_{3}{ }^{-}$(Amberger and Schmit 1987; Aravena et al. 1998; Böttcher et al. 1990; Fukada et al. 2003). The $\delta^{18} \mathrm{O}$ of $\mathrm{NO}_{3}$ has been used to provide more information about the nitrate cycling in groundwater (Amberger and Schmit 1987; Böttcher et al. 1990; Kendall 1998). Typical $\delta^{18} \mathrm{O}$ values of $\mathrm{NO}_{3}{ }^{-}$from nitrification (including $\delta^{18} \mathrm{O}$ values from microbial production of $\mathrm{NH}_{4}{ }^{+}$in fertilizers and precipitation, $\mathrm{NO}_{3}{ }^{-}$derived from both soil $\mathrm{N}$ and manure plus sewage) are lower than that of $\mathrm{NO}_{3}{ }^{-}$from precipitation and $\mathrm{NO}_{3}{ }^{-}$in fertilizer (Xue et al. 2009). The $\delta^{18} \mathrm{O}$ of microbially produced $\mathrm{NO}_{3}{ }^{-}, \mathrm{NO}_{3}{ }^{-}$in precipitation and $\mathrm{NO}_{3}{ }^{-}$ fertilizer are regulated by different processes. During nitrification, about one-third of the oxygen of the $\mathrm{NO}_{3}{ }^{-}$ion is from the atmosphere while two-third is from the groundwater (Andersson and Hooper 1983; Anisfield et al. 2007). Nitrate derived from nitrification should theoretically have $\delta^{18} \mathrm{O}$ values between -10 and $+10 \%$, since environmental water typically has $\delta^{18} \mathrm{O}$ values between -25 and $+4 \%$ and $\delta^{18} \mathrm{O}$ of atmospheric $\mathrm{O}_{2}$ is $+23.5 \%$ (Liu et al. 2006; Xue et al. 2009). The $\delta^{18} \mathrm{O}-\mathrm{NO}_{3}$ of precipitation is controlled by complex atmospheric processes, which result in large spatial and temporal variability in

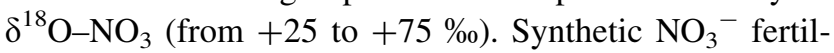
izers have distinctive $\delta^{18} \mathrm{O}$ values (Amberger and Schmit 1987), with a range from +17 to $+25 \%$, as the $\mathrm{O}$ is mainly derived from atmospheric $\mathrm{O}_{2}\left(\delta^{18} \mathrm{O}=+23.5 \%\right)$. Therefore, a dual isotope approach (combination of ${ }^{15} \mathrm{~N}$ and ${ }^{18} \mathrm{O}$ ) can enhance the ability to delineate nitrate sources and transformation processes in groundwater (Aravena and Robertson 1998; Aravena et al. 1993; Panno et al. 2001; Seiler 2005; Widory et al. 2004). Because the Mt. Vulture groundwater is a major source of potable and mineral water in southern Italy, defining origin of groundwater and identifying the possible sources of contamination in this aquifer is essential for determining the causes of increasing $\mathrm{NO}_{3}{ }^{-}$concentrations, and for monitoring groundwater quality in the future. Therefore, the present study has been performed with the following objectives: (1) to report for the first time, in addition to the classical $\delta \mathrm{D}$ and $\delta^{18} \mathrm{O}$ in groundwater, the isotopic values of $\delta^{15} \mathrm{~N}$ and $\delta^{18} \mathrm{O}$ in $\mathrm{NO}_{3}{ }^{-}$, and (2) to trace natural and anthropogenic sources of nitrate in order to identify the transformation processes.

\section{Study area}

Mt. Vulture is a Pleistocene composite volcano $(1.320 \mathrm{~m}$ above sea level) located at the easternmost border of the Apennine compressive front (Fig. 1), at the western margin of the Apulia foreland. The volcanic products are characterized by lavas and pyroclastics ranging in composition from basanites and foidites, to phonolites, with several intermediate rock types (e.g., Beccaluva et al. 2002). The volcanic products lie over Pleistocene gravel and clay, in sub-horizontal layers that cover the intensely deformed flysch sediments of Miocene age. Various conceptual hydrogeological models have been proposed for the Mt. Vulture aquifer. Parisi et al. (2011a) recently conducted a comprehensive isotopic, hydrogeochemical, and hydraulic study that provides a better definition of the recharge and discharge patterns of the Mt. Vulture volcanic aquifer system. The flowing groundwater moves along radial flow paths of various lengths and depths toward the lowest elevations in the south and southeastern parts of the aquifer. The volcano hosts numerous springs and wells emerging from the highest to the lowest elevations around the cone. The volcanic aquifer is comprised of highly permeable units such as coarse pyroclastic layers, fissured lava flows, and fissured tuff, and to a lesser extent of lowpermeability units including fine pyroclastic layers, compact tuff, and palaeosoils. The more permeable units of these various lithological units constitute a unique unconfined aquifer (Spilotro et al. 2006).

According to UNESCO/FAO (1963), the study area has a temperate Mediterranean climate and an annual average temperature of about $13{ }^{\circ} \mathrm{C}$, with a maximum from June to August $\left(22^{\circ} \mathrm{C}\right)$ and a minimum between December and February $\left(\sim 5^{\circ} \mathrm{C}\right)$. The annual average precipitation is about $750 \mathrm{~mm}$, with a maximum amount of rainfall from November to January (Parisi et al. 2011a). The maximum rainfall amounts are associated with the highest elevations of the study area.

In the western area of Mt. Vulture, the soils are principally developed on pyroclastic deposits and are covered by forests, pastures, and fields uncultivated. Beech forests are widespread at higher altitudes while oak and chestnut trees are found at lower altitudes. The soils in the southeastern area of Mt. Vulture have developed mainly on pyroclastic material and colluvial, fluvial, and lacustrine deposits. This area is characterized by active agricultural land use where crops (i.e. wheat, barley, oats) are prevalent. In the southeastern area commercial fertilizers, including urea $\left(\mathrm{CO}\left(\mathrm{NH}_{2}\right)_{2}\right)$ and $\mathrm{N}-\mathrm{P}-\mathrm{K}$ fertilizers with minor pro-portions of lime, ammonium sulfate, $\mathrm{K}$ and $\mathrm{Mg}$ sulfate and $\mathrm{KCl}$, are applied on agricultural fields year-round.

\section{Materials and methods}

Water from 29 springs and operating wells, owned by both companies and private individuals, and used for irrigation and drinking water supply, were collected during a single field trip between January and March 2009. The wells were 


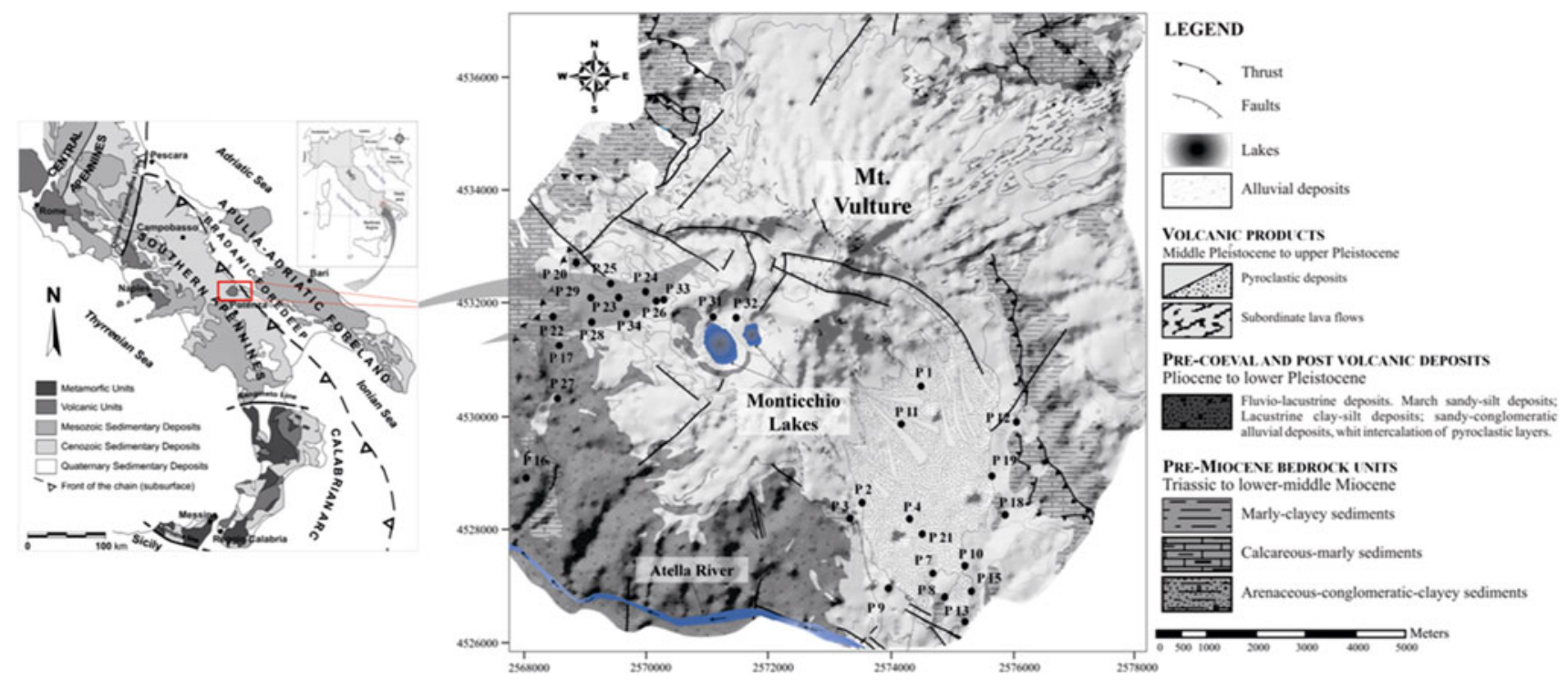

Fig. 1 On the left sketch geological map of the central-southern Italy (from Bonardi et al. 2009). On the right geological setting of Mt. Vulture area (modified from Giannandrea et al. 2004)

sunk to depths of 100-250 m, and were drilled into volcanic products (pyroclastic and effusive rocks). The sampling sites were selected based on the presence of particular hydrogeological and hydrogeochemical features found in the area, which related to the geological context. Sampling sites (Fig. 1) were located mainly in the $\mathrm{W}$ and S-SE sectors of the study area, and within the volcanic products. Some of the sampling sites in the SE sector were located near urban areas. The dissolved $\mathrm{NO}_{3}{ }^{-}$and $\mathrm{NO}_{2}{ }^{-}$were analyzed using ion chromatography at Actlabs Laboratories (Canada), with experimental accuracy better than $\pm 5 \%$. Samples of $\mathrm{NO}_{3}{ }^{-}$for isotopic analysis were collected following the methods described by Chang et al. (1999) and were analyzed for $\delta^{15} \mathrm{~N}$ and $\delta^{18} \mathrm{O}$ in the Isotope Science Laboratory (ISL-UofC) using the denitrifier technique (Casciotti et al. 2002; Sigman et al. 2001). The $\mathrm{N}$ and $\mathrm{O}$ isotope ratios were measured on the produced $\mathrm{N}_{2} \mathrm{O}$ using a Finnigan Mat Delta Plus XL isotope ratio mass spectrometer. The reproducibility of duplicate analyzes was approximately $\pm 0.5 \%$ for $\delta^{15} \mathrm{~N}$ and $\pm 0.7 \%$ for $\delta^{18} \mathrm{O}$. Oxygen isotope compositions were measured on triplicate samples using the $\mathrm{CO}_{2}$-water equilibration technique (Epstein and Mayeda 1953) and hydrogen isotope analyses were performed using the zinc reduction method (Coleman et al. 1982). Stable isotope ratios were measured on a dual inlet Finnigan Delta Plus IRMS with analytical precision of better than $\pm 0.2 \%$ for oxygen and $\pm 1 \%$ for hydrogen. Five water samples calibrated with respect to V-SMOW and GISP International Standards were used as working standards. Stable isotope ratios $\left(\mathrm{D} / \mathrm{H}\right.$ and ${ }^{18} \mathrm{O} /{ }^{16} \mathrm{O}$ ) were provided by the Istituto Nazionale di Geofisica e Vulcanologia (INGV), section of Palermo
(Italy). All the isotope measurements were reported in delta units $(\delta)$ with respect to the V-SMOW international standard (for $\delta^{18} \mathrm{O}$ and $\delta \mathrm{D}$ ) and to atmospheric nitrogen (for $\left.\delta^{15} \mathrm{~N}\right)$.

\section{Results and discussion}

Table 1 summarizes the isotopic and chemical data of the 29 groundwater samples. Groundwaters in the Mt. Vulture area range in temperature from 8.8 to $19.9^{\circ} \mathrm{C}$, pH values from 5.7 to 7.6 , and electrical conductivity from 141 to $4,350 \mu \mathrm{S} / \mathrm{cm}$ (Parisi et al. 2011b). Much of the groundwater has a bicarbonate alkaline-earth and alkaline composition, with the exception of a few springs that are bicarbonate-sulfate-alkaline in composition and show the highest salinity values (Parisi et al. 2011a). Further details of the water chemistry and isotopic composition $\left(\delta \mathrm{D}, \delta^{18} \mathrm{O}\right.$, and $\delta^{13} \mathrm{C}$ ) are summarized in Caracausi et al. (2009), Parisi et al. (2011a, b); Paternoster et al. (2008, 2010). In general, the investigated groundwater not show season variations in major, minor, and trace elements. Most of the Mt. Vulture groundwaters display $\mathrm{CO}_{2}$ partial pressure values that are 1-3 orders of magnitude higher than the atmospheric value. The $\mathrm{CO}_{2}$ in these groundwaters is magmatic in origin (Caracausi et al. 2009; Paternoster 2005). During basalt weathering, $\mathrm{CO}_{2}$ is converted into bicarbonate, which shows a positive correlation with the concentration of major and minor elements. The composition of bicarbonate alkaline-earth and alkaline waters is due to variability in the processes of interaction between water and volcanic rock, and to the dissolved- $\mathrm{CO}_{2}$-rich gases within the 
Table 1 Chemical and isotopic data

\begin{tabular}{|c|c|c|c|c|c|c|c|c|c|c|c|c|c|c|}
\hline $\begin{array}{l}\text { Sample } \\
\text { no. }\end{array}$ & Long.(north) & Lat.(east) & $\begin{array}{l}\text { Elevation } \\
\text { (m a.s.l.) }\end{array}$ & Type & $\begin{array}{l}\text { Well } \\
\text { depth } \\
(\mathrm{m})\end{array}$ & $\begin{array}{l}T^{\mathrm{a}} \\
\left({ }^{\circ} \mathrm{C}\right)\end{array}$ & $\begin{array}{l}\text { Electric } \\
\text { conductivity }^{\mathrm{a}} \\
25^{\circ} \mathrm{C}(\mu \mathrm{S} / \mathrm{cm})\end{array}$ & $\mathrm{pH}^{\mathrm{a}}$ & $\begin{array}{l}\delta^{18} \mathrm{O} \\
(\%)\end{array}$ & $\begin{array}{l}\delta \mathrm{D} \\
(\%)\end{array}$ & $\begin{array}{l}\mathrm{NO}_{2}^{-} \\
(\mathrm{mg} / \\
\mathrm{L})\end{array}$ & $\begin{array}{l}\mathrm{NO}_{3}^{-} \\
(\mathrm{mg} / \\
\mathrm{L})\end{array}$ & $\begin{array}{l}\delta^{15} \mathrm{~N}- \\
\mathrm{NO}_{3} \\
(\%)\end{array}$ & $\begin{array}{l}\delta^{18} \mathrm{O}- \\
\mathrm{NO}_{3} \\
(\%)\end{array}$ \\
\hline $\mathrm{P} 1$ & $4,531,210$ & 555,380 & 545 & W & 150 & 13.0 & 350 & 6.6 & -8.5 & -54 & $<0.1$ & 43.2 & 7.3 & -1.9 \\
\hline $\mathrm{P} 2$ & $4,528,490$ & 554,302 & 544 & W & 96 & 15.2 & 237 & 6.8 & -8.7 & -54 & $<0.1$ & 30.8 & 3.7 & 1.0 \\
\hline $\mathrm{P} 3$ & $4,528,250$ & 554,060 & 600 & $\mathrm{~W}$ & 132 & 17.2 & 233 & 7.5 & -8.9 & -55 & $<0.1$ & 23.1 & 4.1 & 1.4 \\
\hline $\mathrm{P} 4$ & $4,528,240$ & 555,360 & 545 & $\mathrm{~W}$ & 128 & 15.0 & 304 & 6.1 & -9.0 & -55 & $<0.1$ & 15.5 & 4.2 & 1.9 \\
\hline P7 & $4,526,900$ & 556,320 & 490 & W & n.m. & 15.3 & 607 & 6.1 & -9.4 & -57 & $<0.1$ & 16.9 & 4.2 & 0.5 \\
\hline P8 & $4,526,817$ & 556,303 & 490 & $\mathrm{~W}$ & n.m. & 14.1 & 478 & 6.9 & -8.8 & -55 & $<0.1$ & 26.6 & 4.8 & 2.1 \\
\hline P9 & $4,526,707$ & 556,342 & 490 & $\mathrm{~W}$ & n.m. & 13.8 & 430 & 6.9 & -8.5 & -54 & $<0.1$ & 28.5 & 3.5 & -0.5 \\
\hline $\mathrm{P} 10$ & $4,526,605$ & 556,340 & 483 & W & 120 & 16.0 & 291 & 7.0 & -8.3 & -52 & $<0.1$ & 40.7 & 6.1 & 3.2 \\
\hline P11 & $4,531,235$ & 555467 & 555 & W & 150 & 13.1 & 234 & 6.2 & -9.3 & -55 & $<0.1$ & 16.4 & 4.3 & -0.8 \\
\hline $\mathrm{P} 12$ & $4,534,820$ & 557,160 & 519 & W & 133 & 15.7 & 265 & 6.5 & -8.6 & -53 & $<0.1$ & 11.1 & 5.0 & -1.0 \\
\hline $\mathrm{P} 13$ & $4,525,820$ & 555,300 & 474 & S & - & 15.7 & 763 & 5.9 & -8.6 & -54 & $<0.1$ & 12.8 & 6.2 & 1.0 \\
\hline $\mathrm{P} 15$ & $4,526,955$ & 556,359 & 487 & W & 130 & 14.7 & 896 & 5.9 & -9.1 & -57 & $<0.1$ & 22.2 & 3.2 & 1.7 \\
\hline P18 & $4,527,726$ & 556,960 & 550 & W & 180 & 15.0 & 370 & 5.9 & -8.6 & -55 & $<0.1$ & 33.2 & 7.6 & 2.5 \\
\hline P19 & $4,527,739$ & 556,970 & 552 & W & 132 & 16.1 & 362 & 6.3 & -9.3 & -58 & $<0.1$ & 8.0 & 3.8 & -1.9 \\
\hline $\mathrm{P} 21$ & $4,526,870$ & 556,607 & 493 & W & 160 & 16.1 & 435 & 6.1 & -9.3 & -57 & $<0.1$ & 7.9 & 3.3 & 2.1 \\
\hline $\mathrm{P} 20$ & $4,527,726$ & 555,196 & 554 & W & 250 & 18.5 & 1,717 & 6.3 & -9.8 & -60 & $<0.1$ & 2.2 & 9.7 & n.m. \\
\hline $\mathrm{P} 17$ & $4,526,867$ & 552,828 & 449 & $S$ & - & 17.0 & 4,350 & 6.5 & -8.5 & -53 & $<0.1$ & 3.1 & 11.9 & n.m. \\
\hline $\mathrm{P} 22$ & $4,532,983$ & 547,976 & 547 & $S$ & - & 17.4 & 2,149 & 6.2 & -9.4 & -56 & $<0.1$ & 0.9 & 6.5 & 3.1 \\
\hline $\mathrm{P} 23$ & $4,533,314$ & 549,828 & 566 & W & 183 & 16.8 & 750 & 5.9 & -9.5 & -57 & $<0.1$ & 3.5 & 6.7 & 2.8 \\
\hline $\mathrm{P} 26$ & $4,532,938$ & 551,154 & 690 & W & 157 & 19.5 & 1,147 & 6.0 & -9.6 & -57 & $<0.1$ & 2.1 & 7.0 & 4.1 \\
\hline $\mathrm{P} 28$ & $4,532,832$ & 549,658 & 650 & W & 96 & 19.9 & 1,346 & 6.1 & -9.6 & -58 & $<0.1$ & 1.9 & 11.3 & 3.9 \\
\hline P29 & $4,533,100$ & 549,100 & 644 & W & 202 & 19.5 & 918 & 5.9 & -8.3 & -52 & $<0.1$ & 3.1 & 6.1 & 0.4 \\
\hline $\mathrm{P} 24$ & $4,533,306$ & 550,031 & 565 & W & 208 & 18.1 & 1,480 & 6.0 & -9.6 & -57 & $<0.1$ & 0.9 & 4.2 & 4.1 \\
\hline $\mathrm{P} 25$ & $4,533,379$ & 549,532 & 657 & W & 643 & 14.0 & 351 & 6.1 & -9.1 & -53 & $<0.1$ & 1.3 & 2.5 & 2.9 \\
\hline $\mathrm{P} 27$ & $4,530,603$ & 547,666 & 682 & W & 144 & 18.9 & 698 & 5.9 & -9.4 & -55 & $<0.1$ & 1.9 & 4.3 & 0.3 \\
\hline P31 & $4,532,900$ & 551,950 & 885 & S & - & 9.6 & 206 & 7.6 & -9.7 & -60 & $<0.1$ & 0.6 & 4.3 & 1.7 \\
\hline P32 & $4,533,066$ & 552,194 & 960 & S & - & 8.8 & 141 & 7.0 & -9.6 & -59 & $<0.1$ & 2.9 & 2.4 & 0.6 \\
\hline P33 & $4,532,966$ & 551,315 & 780 & W & 251 & 15.8 & 369 & 5.9 & -9.3 & -55 & $<0.1$ & 1.8 & 4.6 & 0.9 \\
\hline P34 & $4,532,930$ & 550,040 & 735 & $\mathrm{~W}$ & 202 & 16.5 & 448 & 5.7 & -9.2 & -57 & $<0.1$ & 2.6 & 3.6 & 0.8 \\
\hline
\end{tabular}

The location of sampling point are provided in UTM Zone 33 coordinates using the European Datum of 1950

n.m. not measured, $S$ spring, $W$ well

${ }^{\text {a }}$ Data from Parisi et al. (2011b)

flowing groundwaters. In contrast, the bicarbonate-sulfatealkaline waters showing the highest salinity values are related to prolonged water circulation in alkali and feldspathoid-rich pyroclastic layers.

The samples had $\delta \mathrm{D}$ and $\delta^{18} \mathrm{O}$ isotopic compositions ranging between -8.3 and $-9.7 \%$ for oxygen, and -62 and $-52 \%$ for deuterium. In the binary diagram $\delta \mathrm{D}-\delta^{18} \mathrm{O}$ (Fig. 2), the investigated groundwater samples lie close to the local meteoric water line (LMWL; Paternoster et al. 2008), indicating that samples was not affected by secondary processes after rainfall (e.g., evaporation, evapotranspiration). Consequently, the water samples are retained as meteoric in origin. The measured isotopic data are in the range of the values reported by Parisi et al. (2011a) and Paternoster et al. (2008), which excluded any significant seasonal variation. The nitrate concentration ranged from 0.6 to $43.2 \mathrm{mg} / \mathrm{L}$, with an average value of $12.6 \mathrm{mg} / \mathrm{L}$. However, substantial differences in $\mathrm{NO}_{3}{ }^{-}$ concentration were found between the western and southeastern areas of the Mt. Vulture aquifer. In the southeastern area, groundwaters had higher $\mathrm{NO}_{3}{ }^{-}$concentrations $\left(\mathrm{NO}_{3}{ }^{-}>8 \mathrm{mg} / \mathrm{L}\right)$ than in the western part $\left(\mathrm{NO}_{3}{ }^{-}<4 \mathrm{mg} / \mathrm{L}\right)$. $\mathrm{NO}_{2}{ }^{-}$concentrations were below the detection limit $(0.1 \mathrm{mg} / \mathrm{L})$ in almost all waters. The values of $\delta^{15} \mathrm{~N}-\mathrm{NO}_{3}$ ranged from +2.4 to $+11.9 \%$, and $\delta^{18} \mathrm{O}-\mathrm{NO}_{3}$ from -1.9 to $+4.1 \%$. In the southeastern area, $\delta^{15} \mathrm{~N}-\mathrm{NO}_{3}$ values range between +3.2 and $+7.6 \%$ while $\delta^{18} \mathrm{O}-\mathrm{NO}_{3}$ data between -1.9 and $+3.2 \%$. The $\delta{ }^{15} \mathrm{~N}-\mathrm{NO}_{3}$ and $\delta^{18} \mathrm{O}-\mathrm{NO}_{3}$ 


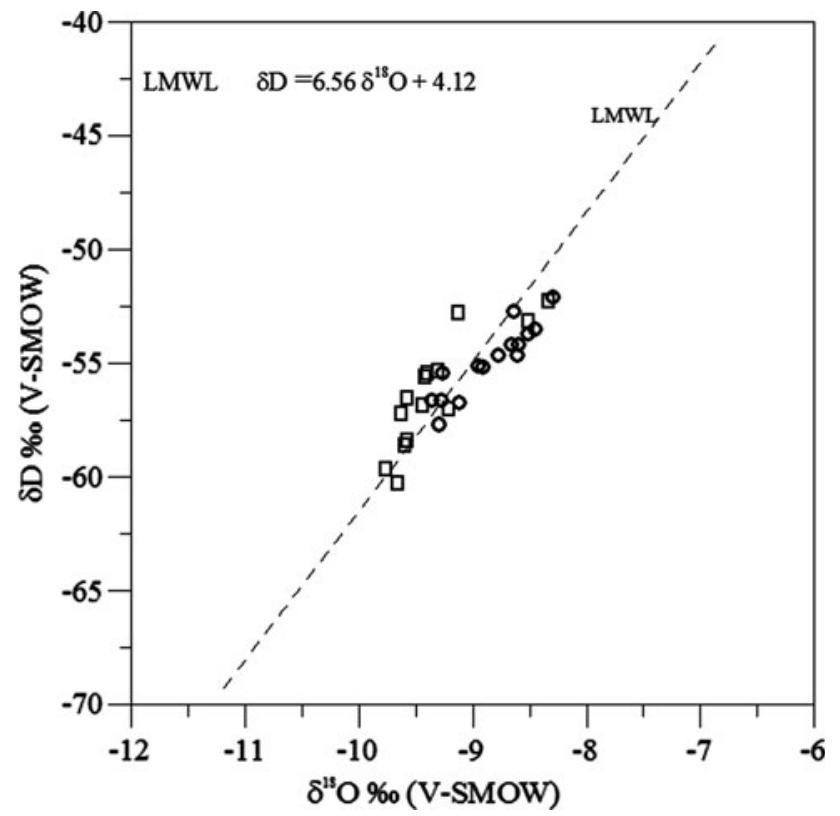

Fig. $2 \delta^{18} \mathrm{O}$ and $\delta \mathrm{D}$ plot of groundwater samples. Circle and square represent groundwaters from southeastern and western area, respectively

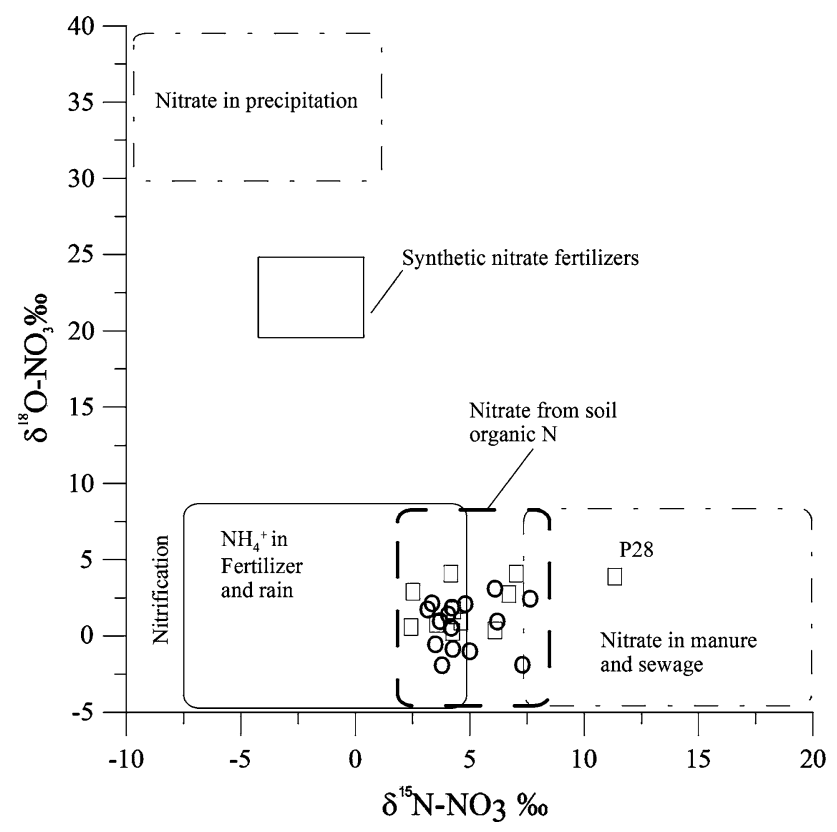

Fig. 3 Pattern of typical ranges of $\delta^{18} \mathrm{O}$ and $\delta^{15} \mathrm{~N}$ for different nitrate sources (after Choi et al. 2011) and values measured in Mt. Vulture area

values of groundwater in the western area ranged from +2.4 to $+11.9 \%$ and between 0.3 and $+4.1 \%$, respectively. For two groundwaters (P20 and P17 samples), the $\delta^{18} \mathrm{O}$ values were not reported because of high uncertainty.

Source of nitrate and its behavior

The dual-isotope approach $\left(\delta^{15} \mathrm{~N}-\mathrm{NO}_{3}\right.$ and $\left.\delta^{18} \mathrm{O}-\mathrm{NO}_{3}\right)$ provide a useful method for identifying the origin of $\mathrm{NO}_{3}{ }^{-}$ and fractionation processes that nitrate has undergone in aquifer system (Panno et al. 2001). The boxes in Fig. 3 show typical ranges of $\delta^{15} \mathrm{~N}$ and $\delta^{18} \mathrm{O}$ deriving from various natural and anthropogenic sources of $\mathrm{NO}_{3}{ }^{-}$(after Choi et al. 2011). $\mathrm{NO}_{3}{ }^{-}$originating from both precipitation and synthetic $\mathrm{NO}_{3}{ }^{-}$fertilizer has much higher $\delta^{18} \mathrm{O}$ values than that resulting from nitrification of reduced $\mathrm{N}$ sources (i.e. fertilizer applied as $\mathrm{NH}_{4}{ }^{+}$and urea, soil organic $\mathrm{N}$, and $\mathrm{NH}_{4}{ }^{+}$from sewage and manure). The nitrate deriving from these forms of reduced $\mathrm{N}$ can be distinguished by its $\delta^{15} \mathrm{~N}-$ $\mathrm{NO}_{3}$ value, although a some degree of overlap. The investigated water samples have $\delta^{15} \mathrm{~N}-\mathrm{NO}_{3}$ and $\delta^{18} \mathrm{O}-\mathrm{NO}_{3}$ values within the observed range of both soil organic $\mathrm{N}$ and inorganic fertilizer (Choi et al. 2011; Kendall 1998). Only one water (P28 sample) has high $\delta^{15} \mathrm{~N}-\mathrm{NO}_{3}$ values and overlap the range of nitrate from manure and septic waste (Kendall 1998; Xue et al. 2009). More in general, a negative correlation between $\delta^{15} \mathrm{~N}$ (and $\delta^{18} \mathrm{O}$ ) and $\mathrm{NO}_{3}{ }^{-}$ concentrations is not observed (Fig. 4a, b, respectively). Although there are no baseline data on the level of natural $\mathrm{NO}_{3}{ }^{-}$concentrations in this area, nitrate values above $4 \mathrm{mg} / \mathrm{L}$ may be retained as due to anthropogenic contamination, according to Babiker et al. (2004) and Burkart and Kolpin (1993). Therefore, the $\mathrm{NO}_{3}^{-}$concentrations of $8-43 \mathrm{mg} / \mathrm{L}$ of groundwater from southeastern area are too high to assume that the source of $\mathrm{NO}_{3}{ }^{-}$is natural soil nitrogen. We postulate that the high $\mathrm{NO}_{3}{ }^{-}$concentrations and the measured $\delta^{15} \mathrm{~N}$ values are due to anthropogenic contamination (inorganic fertilizers). This interpretation is consistent with the fact that the southeastern area contains crop farming. The most of samples from the western area are characterized by $\delta^{15} \mathrm{~N}-\mathrm{NO}_{3}$ values in the range from +2.4 to $+7.0 \%$ and $\mathrm{NO}_{3}{ }^{-}$concentrations lower than $4 \mathrm{mg} / \mathrm{L}$, highlighting that the source of nitrate is soil organic $\mathrm{N}$. The anomalously heavy $\delta^{15} \mathrm{~N}$ values observed in three samples (P20, P17, and P28) may suggest that a significant contribution of $\mathrm{NO}_{3}{ }^{-}$from an isotopically heavy $\delta^{15} \mathrm{~N}$ source is present. Since these samples have low $\mathrm{NO}_{3}{ }^{-}$concentrations and relatively high values of $\delta^{15} \mathrm{~N}$ they could be affected by denitrification. Kendall (1998) suggested that denitrification is usually associated with both a significant increase in alkalinity, resulting from the oxidation of organic matter, and the presence of dissolved $\mathrm{Mn}$ and $\mathrm{Fe}$, due to the dissolution of Fe- and Mn-minerals. The P20, P17, and P28 samples are characterized by very high contents of dissolved $\mathrm{Mn}$ and $\mathrm{Fe}$ due to the redox reactions occurring in the system (Parisi et al. 2011b). Overall this points toward the existence of a redox gradient involving a placed nitrate reduction.

Values of $\delta^{18} \mathrm{O}-\mathrm{NO}_{3}$ provided a further indication of sources and transformation of nitrate in groundwater. The $\delta^{18} \mathrm{O}$ values of $\mathrm{NO}_{3}{ }^{-}$in groundwater (Fig. 4b) range from -1.9 to $+4.1 \%$. It is known, that $\mathrm{NH}_{4}{ }^{+}$and $\mathrm{NO}_{3}{ }^{-}$from 
Fig. 4 a $\delta^{15} \mathrm{~N}$ composition of dissolved $\mathrm{NO}_{3}{ }^{-}$versus $\mathrm{NO}_{3}{ }^{-}$ concentrations. The box shows $\delta^{15} \mathrm{~N}-\mathrm{NO}_{3}$ values of soil source of nitrate (Kendall 1998); b $\delta^{18} \mathrm{O}$ composition of dissolved $\mathrm{NO}_{3}{ }^{-}$versus $\mathrm{NO}_{3}{ }^{-}$ concentrations. The estimated range of $\delta^{18} \mathrm{O}$ values for nitrate derived from nitrification is shown. Symbols as in Fig. 2
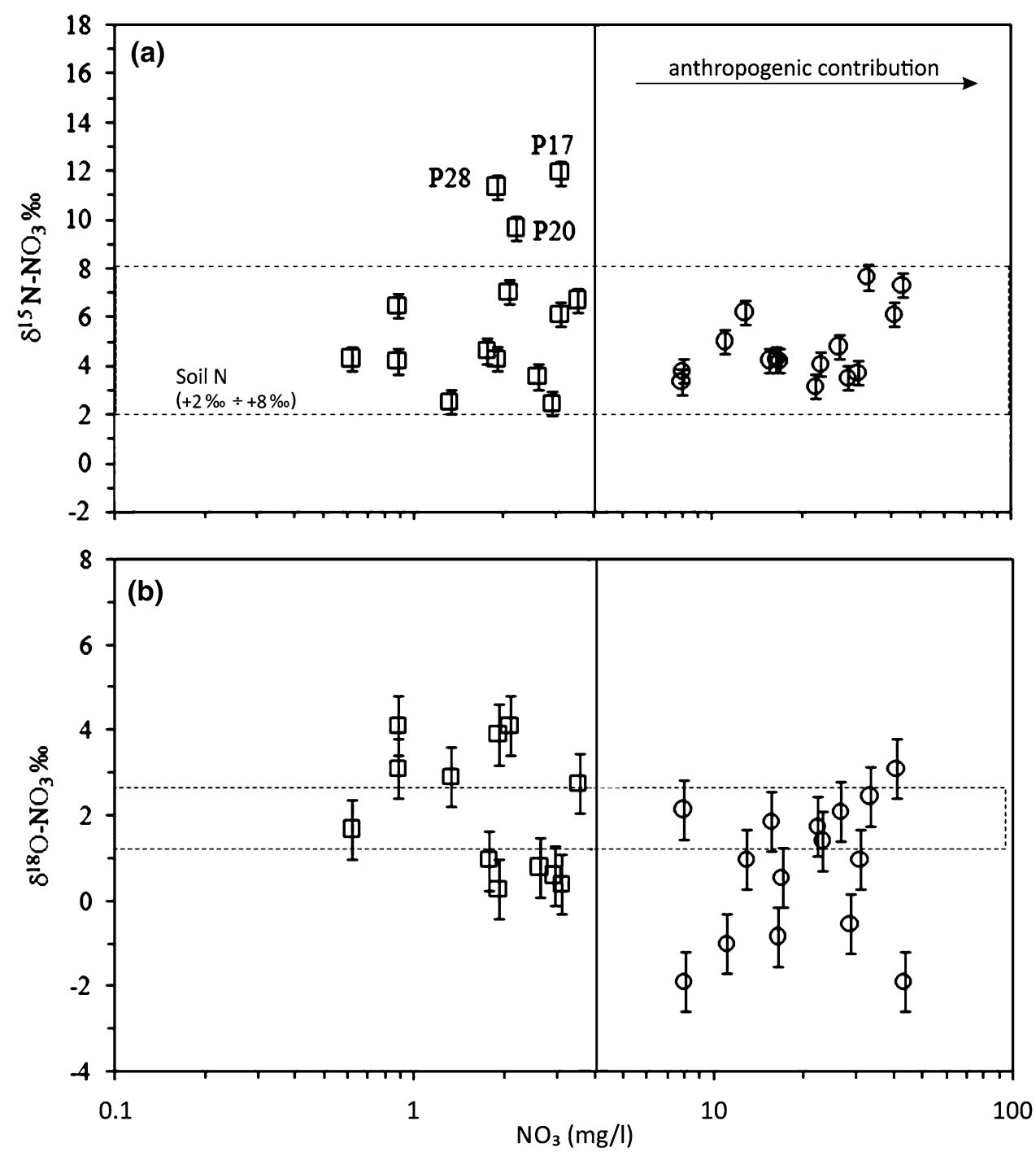

chemical fertilizers are rapidly immobilized as organic $\mathrm{N}$ in agricultural soils (Mengis et al. 2001). Based on experimental studies, it is suggested that $\mathrm{NO}_{3}{ }^{-}$produced during nitrification should contain two-third of the oxygen from soil water and one-third of the oxygen from atmospheric oxygen (Anisfield et al. 2007; Aravena et al. 1993; Liu et al. 2006; Wassenaar 1995). Assuming the oxygen from these sources is incorporated without isotope fractionation (Mayer et al. 2001), the $\delta^{18} \mathrm{O}-\mathrm{NO}_{3}$ value of the newly formed $\mathrm{NO}_{3}$ can be calculated as shown below (Fukada et al. 2004):

$\delta^{18} \mathrm{O}-\mathrm{NO}_{3}=(2 / 3)\left(\delta^{18} \mathrm{O}-\mathrm{H}_{2} \mathrm{O}\right)+(13)\left(\delta^{18} \mathrm{O}-\mathrm{O}_{2}\right)$

Since the measured $\delta^{18} \mathrm{O}$ values of groundwater in the study area range between -8.3 and $-9.8 \%$ and the $\delta^{18} \mathrm{O}-\mathrm{O}_{2}$ for molecular oxygen is $+23.5 \%$ ( Liu et al. 2006; Xue et al. 2009), the expected $\delta^{18} \mathrm{O}-\mathrm{NO}_{3}$ values for nitrate derived from nitrification would then be from +1.3 to $+2.3 \%$. However, it has to be stressed that this expected local nitrate $\delta^{18} \mathrm{O}$ range is rather simplified, because the relative contribution of ambient $\mathrm{O}$ from surrounding water and $\mathrm{O}_{2}$ has been found not always keeping the rule of 2:1 (Mayer et al. 2001). Bearing in mind the uncertainties and assumptions in the use of Eq. (1), it is worth of note that these theoretically expected values correspond exactly to the middle of the range of values measured for nitrate in groundwater $\left(\delta^{18} \mathrm{O}-\mathrm{NO}_{3}\right.$ from -1.9 to $+4.1 \%$ ). Thus, we believe that the low measured $\delta^{18} \mathrm{O}$ values indicate that nitrification occurred in both the investigated areas.

\section{Conclusion}

The isotopic data $\left(\delta^{18} \mathrm{O}\right.$ and $\left.\delta \mathrm{D}\right)$ of the investigated groundwater indicate that are meteoric in origin. $\mathrm{NO}_{3}{ }^{-}$ contents allowed us to discriminate the western area from the southeastern areas. In water samples from the 
southeastern area, $\mathrm{NO}_{3}{ }^{-}$contents above $8 \mathrm{mg} / \mathrm{L}$ were detected, $\delta{ }^{15} \mathrm{~N}-\mathrm{NO}_{3}$ isotopic values suggest that $\mathrm{NO}_{3}{ }^{-}$ originated from anthropogenic contamination (inorganic fertilizers). The measured low $\delta^{18} \mathrm{O}$ values indicate that groundwater nitrate derived from nitrification of inorganic fertilizers in an area affected by active agricultural land use. In groundwater from the western area, the $\mathrm{NO}_{3}{ }^{-}$ content was lower, and the $\delta^{15} \mathrm{~N}-\mathrm{NO}_{3}$ values generally suggest a natural $\mathrm{NO}_{3}{ }^{-}$origin from organic soil $\mathrm{N}$. In addition, the low $\delta^{18} \mathrm{O}$ values indicate that groundwater nitrate derives from nitrification of organic soil N. However, for a few samples located in this area showing relatively heavy $\delta^{15} \mathrm{~N}$ values and low concentrations of nitrate a placed nitrate reduction could not be excluded.

Acknowledgments The paper was financially supported by a grant (RIL 2009-Unibas) of G. Mongelli and M. Paternoster. Many thanks to Gaudianello, Traficante and Itala companies for the permission to sample water. We are also grateful to S. Parisi for her support during fieldwork. We thank two anonymous referees for their helpful comments.

\section{References}

Amberger A, Schmit HL (1987) Naturliche isotopengehalte von nitratals indikatoren fur dessen Herkunft. Geochim Cosmochim Acta 51:2699-2705

Andersson KK, Hooper AB (1983) $\mathrm{O}_{2}$ and $\mathrm{H}_{2} \mathrm{O}$ are each the source of one $\mathrm{O}$ in $\mathrm{NO}_{2}{ }^{-}$produced from $\mathrm{NH}_{3}$ by Nitrosomonas: ${ }^{15} \mathrm{NNMR}$ evidence. FEBS Lett 64:236-240

Anisfield SC, Barnes RT, Altabet MA, Wu T (2007) Isotopic apportionment of atmospheric and sewage nitrogen sources in two Connecticut rivers. Environ Sci Technol 41:6363-6369

Aravena R, Robertson WD (1998) Use of multiple isotope tracers to evaluate denitrification in ground water: study of nitrate from a large-flux septic system plume. Ground Water 36:975-982

Aravena R, Evans ML, Cherry JA (1993) Stable isotopes of oxygen and nitrogen in source identification of nitrate from septic systems. Ground Water 31:180-186

Babiker IS, Mohamed AA, Terao H, Kato K, Ohta K (2004) Assessment of groundwater contamination by nitrate leaching from intensive vegetable cultivation using geographical information system. Environ Int 35:1009-1017

Beccaluva L, Coltorti M, Di Girolamo P, Melluso L, Dilani L, Morra V, Siena E (2002) Petrogenesis and evolution of Mt. Vulture alkaline volcanism (southern Italy). Miner Petrol 74:277-297

Benkovitz CM, Scholtz MT, Pacyna J, Tarrason L, Dignon J, Voldner EC, Spiro PA, Logan JA, Graedel TE (1996) Global gridded inventories of anthropogenic emissions of sulfur and nitrogen. Geophys Res 101:29239-29253

Bonardi G, Ciarcia S, Di Nocera S, Matano F, Sgrosso I, Torre M (2009) Carta delle principali unità cinematiche dell'Appennino meridionale: nota illustrativa. Boll Soc Geol It 128:47-60

Böttcher J, Strebel O, Voerkelius S, Schmidt HL (1990) Using isotope fractionation of nitrate-nitrogen and nitrate-oxygen for evaluation of microbial denitrification in a sandy aquifer. J Hydrol 114:413-424

Burkart MR, Kolpin DW (1993) Hydrogeological and land-use factors associated with herbicide and nitrate occurrence in nearsurface aquifers. J Environ Qual 22:646-656
Caracausi A, Nuccio PM, Favara R, Nicolosi M, Paternoster M (2009) Gas hazard assessment at the Monticchio crater lakes of Mt. Vulture, a volcano in Southern Italy. Terra Nova 21:83-87

Casciotti KL, Sigman DM, Galanter Hastings M, Böhlke JK, Hilkert A (2002) Measurement of the oxygen isotopic composition of nitrate in seawater and freshwater using the denitrifier method. Anal Chem 74:4905-4912

Chae GT, Yun ST, Mayer B, Choi BY, Kim KH, Kwona JS, Yu SY (2009) Hydrochemical and stable isotopic assessment of nitrate contamination in an alluvial aquifer underneath a riverside agricultural field. Agric Water Manag 96:1819-1827

Chang CCY, Langston J, Riggs M, Campbell DH, Silva SR, Kendall C (1999) A method for nitrate collection for ${ }^{15} \mathrm{~N}$ and ${ }^{18} \mathrm{O}$ analysis from waters with low nitrate concentrations. Can J Fish Aquat Sci 56:1856-1864

Choi WJ, Han GH, Lee SM, Lee GT, Yoon KS, Choi SM, Ro HM (2007) Impact of land-use types on nitrate concentration and $\delta^{15} \mathrm{~N}$ in unconfined groundwater in rural areas of Korea. Agric Ecosyst Environ 120:259-268

Choi BY, Yun ST, Mayer B, Kim KH (2011) Sources and biogeochemical behavior of nitrate and sulfate in an alluvial aquifer: Hydrochemical and stable isotope approaches. Appl Geochem 26:1249-1260

Coleman ML, Stephen TJ, Durham JJ, Rousse JB, Moore GR (1982) Reduction of water with zinc for hydrogen analysis. Ann Chem 54:993-995

EU Directive, 1998/83/EC. Council Directive of 3 November 1998 on the quality of water intended for human consumption 1998 Official Journal of the European Union L33032 5.12.1998

EU Directive, 2003/40/EC. Council Directive of 16 May 2003 establishing the list, concentration limits and labeling requirements for the constituents of natural mineral waters and the conditions for using ozone-enriched air for the treatment of natural mineral waters and spring waters. Official Journal of the European Union L126/34 22/05/2003

Epstein S, Mayeda TK (1953) Variations of the ${ }^{18} \mathrm{O} /{ }^{16} \mathrm{O}$ ratios in natural waters. Geochim Cosmochim Acta 4:213-224

Fukada T, Hiscock KM, Dennis PF, Grischek T (2003) A dual isotope approach to identify denitrification in ground water at a river bank infiltration site. Water Res 37:3070-3078

Fukada T, Hiscock KM, Dennis PF (2004) A dual isotope approach to the nitrogen hydrochemistry of an urban aquifer. Appl Geochem 19:709-719

Giannandrea P, La Volpe L, Principe C, Schiattarella M (2004) Carta geologica del Monte Vulture alla scala 1:25.000. Litografia Artistica Cartografica Firenze

Heaton THE (1986) Isotopic studies of nitrogen pollution in the hydrosphere and atmosphere: A review. Chem Geol 59:87-102

Kendall C (1998) Tracing sources and cycling of nitrate in catchments. In: Kendall C, McDonnell JJ (eds) Isotope tracers in catchment hydrology. Elsevier, Amsterdam, pp 519-576

Liu CQ, Li SL, Lang YC, Xiao HY (2006) Using $\delta^{15} \mathrm{~N}$ and $\delta^{18} \mathrm{O}$ values to identify nitrate sources in karst ground water, Guiyang, Southwest China. Environ Sci Technol 40:6928-6933

Mayer B, Bollwerk SM, Mansfeldt T, Hütter B, Veizer J (2001) The oxygen isotope composition of nitrate generated by nitrification in acid forest floors. Geochim Cosmochim Acta 65:2743-2756

Mengis M, Walther U, Bernasconi SM, Wehrli B (2001) Limitations of using $\delta^{18} \mathrm{O}$ for the source identification of nitrate in agricultural soils. Environ Sci Technol 35:1840-1844

Panno SV, Hackley KC, Hwang HH, Kelly WR (2001) Determination of the sources of nitrate contamination in karst springs using isotopic and chemical indicators. Chem Geol 179:113-128

Parisi S, Paternoster M, Kohfahl C, Pekdeger A, Meyer H, Hubberten HW, Spilotro G, Mongelli G (2011a) Groundwater recharge areas of a volcanic aquifer system inferred from hydraulic, 
hydrogeochemical and stable isotope data: Mount Vulture, southern Italy. Hydrog J 19:133-153

Parisi S, Paternoster M, Perri F, Mongelli G (2011b) Source and mobility of minor and trace elements in a volcanic aquifer system: Mt. Vulture (southern Italy). J Geoch Expl 110:233-244

Paternoster M (2005) Mt. Vulture volcano (Italy): a geochemical contribution to the origin of fluids and to a better definition of its geodynamic setting. Ph.D. Dissertation, University of Palermo

Paternoster M, Liotta M, Favara R (2008) Stable isotope ratios in meteoric recharge and groundwater at Mt.Vulture volcano, southern Italy. J Hydrol 348:87-97

Paternoster M, Parisi S, Caracausi A, Favara R, Mongelli G (2010) Groundwaters of Mt. Vulture volcano, southern Italy: chemistry and sulfur isotope composition of dissolved sulfate. Geochem J 44:125-135

Seiler RL (2005) Combined use of ${ }^{15} \mathrm{~N}$ and ${ }^{18} \mathrm{O}$ of nitrate and ${ }^{11} \mathrm{~B}$ to evaluate nitrate contamination in groundwater. Appl Geochem 20:1626-1636

Sigman DM, Casciotti KL, Andreani M, Barford C, Galanter M, Bahlke JK (2001) A bacterial method for the nitrogen isotopic analysis of nitrate in seawater and freshwater. Anal Chem 28:4145-4153

Silva SR, Kendall C, Wilkinson DH, Chang CCY, Zeigler AC, Avanzino R (2000) A new method for collection of nitrate from fresh water and the analysis of nitrogen and oxygen ratios. J Hydrol 228:22-36
Silva SR, Ging PB, Lee RW, Ebbert JC, Tesoriero AJ, Inkpen EL (2002) Forensic applications of nitrogen and oxygen isotopes in tracing nitrate sources in urban environments. Environ Forensics 3:125-130

Singleton MJ, Esser BK, Moran JE, Hudson GB, McNab WW, Harter T (2007) Saturated zone denitrification: potential for natural attenuation of nitrate contamination in shallow groundwater under dairy operations. Environ Sci Technol 41:759-765

Spilotro G, Canora F, Caporale F, Caputo R, Fidelibus MD, Leandro G (2006) Idrogeologia del Monte Vulture [Hydrogeology of M. Vulture]. In: Principe C (ed) La geologia del Monte Vulture [The geology of the Mount Vulture]. Regione Basilicata, Potenza, Italy

UNESCO/FAO (1963) Carte bioclimatique de la Zone Méditerrané [Bioclimatic map of the Mediterranean zone]. UNESCO, New York, FAO, Rome

Wassenaar LI (1995) Evaluation of the origin and fate of nitrate in the Abbotsford aquifer using the isotopes of ${ }^{15} \mathrm{~N}$ and ${ }^{18} \mathrm{O}$ in $\mathrm{NO}_{3}$. Appl Geochem 10:391-405

Widory D, Kloppmann W, Chery L, Bonnin J, Rochdi H, Guinamant JL (2004) Nitrate in groundwater, an isotope multi-tracer approach. J Contam Hydrol 72:165-188

Xue D, Bottea J, De Baets B, Accoe F, Nestler A, Taylor P, Van Cleemput O, Berglund M, Boeckx P (2009) Present limitations and future prospects of stable isotope methods for nitrate source identification in surface and groundwater. Water Res 43:1159-1170 